\title{
PENGARUH CAR, NPF DAN FDR TERHADAP PROFITABILITAS BANK SYARIAH DI INDONESIA
}

\author{
${ }^{1}$ Medina Almunawwaroh, ${ }^{2}$ Rina Marliana \\ 1,2 Program Studi Akuntansi, Fakultas Ekonomi, Universitas Siliwangi \\ Jl. Siliwangi No. 24 Kota Tasikmalaya 46115 \\ ${ }^{1}$ medinaalmunawaroh@unsil.ac.id, ${ }^{2}$ rinamarliana@unsil.ac.id
}

\begin{abstract}
Abstrak : Penelitian ini dilakukan untuk menguji pengaruh Capital Adequacy Ratio (CAR), Non Performing Financing (NPF) dan Financing To Deposit Ratio (FDR) terhadap Profitabilitas (ROA). Selama periode pengamatan menunjukkan bahwa data penelitian berdistribusi normal. Berdasarkan uji normalitas, uji multikolinearitas, uji heteroskedastisitas, dan uji autokorelasi tidak ditemukan variabel yang menyimpang dari asumsi klasik. Hal ini menunjukkan data yang tersedia telah memenuhi syarat menggunakan model persamaan regresi linier berganda. Hasil penelitian ini menunjukkan bahwa Capital Adequacy Ratio (CAR) dan Non Performing Financing (NPF) berpengaruh negatif signifikan terhadap Profitabilitas (ROA) sedangkan Financing To Deposit Ratio (FDR) menunjukkan pengaruh yang positif signifikan terhadap Profitabilitas (ROA). Kemampuan prediksi dari ketiga variabel tersebut terhadap profitabilitas (ROA)dalam penelitian ini sebesar 80,9\%, sedangkan sisanya $19,1 \%$ dipengaruhi oleh faktor lain yang tidak dimasukkan ke dalam model penelitian.
\end{abstract}

\section{Kata Kunci: CAR, NPF, FDR}

Abstract : This research was aimed at examining the influence of Capital Adequacy Ratio (CAR), Non Performing Financing (NPF) and Financing To Deposit Ratio (FDR) to Profitability (ROA). During the period of observation, data were normally distributed. Based on normality, multicollinearity, heteroscedasticity and autocorrelation tests, deviation of classical assumptions of variables were not found. It shows that the available data were qualified to be examined with multiple linear regression model. The results of this study show that the Capital Adequacy Ratio (CAR) and Non Performing Financing (NPF) indicate significant negative impact on Profitability (ROA). Financing To Deposit Ratio (FDR) showed a significant positive effect on profitability (ROA).The predictive ability of these variables on Profitability (ROA )in this study was 80.9\%, while the remaining $19.1 \%$ was influenced by other factors not included in the study.

Keywords: $C A R, N P F, F D R$

\section{PENDAHULUAN}

Ketika sektor ekonomi mengalami penurunan maka salah satu cara mengembalikan stabilitas ekonomi adalah menata sektor perbankan tidak terkecuali perbankan syariah. Di Indonesia pelopor perbankan syariah adalah Bank Muamalat
Indonesia yang lahir pada tahun 1991. Dasar perbankan syariah mengacu kepada ajaran Agama Islam yang bersumber pada Al Qur'an, Al Hadits, dan Ijtihad. Bank Syariah adalah bank yang kegiatan usahanya dilakukan berdasarkan prinsip syariah. Sedangkan prinsip syariah adalah aturan perjanjian berdasarkan hukum Islam

Received: 2017-10-23 | Reviced: 2018-01-23 | Accepted: 2018-01-31

Indexed : DOAJ, Garuda, Crossref, Google Scholar | DOI : https://doi.org/10.29313/amwaluna.v2i1.3156 
(UU No. 21/2008 tentang Perbankan Syariah).

Di Indonesia saat ini organisasi bisnis islam yang berkembang salah satunya adalah bank syariah. Pada perbankan syariah, bank berperan sebagai manajer investasi dari pemilik dana atas investasi yang disimpan di bank. Hubungan antara bank syariah dengan nasabah dalam praktek perbankan syariah bersifat kemitraan. Salah satu penyebab yang menjadikan bank syariah terus mengalami peningkatan adalah mekanisme pembagian keuntungannya yang berdasarkan bagi hasil.

Peran bank syariah sebagai lembaga yang bertujuan mendukung pelaksanaan pembangunan nasional, mempunyai kegiatan utama yaitu menghimpun dana dari masyarakat dan menyalurkan dana kepada masyarakat. Kegiatan penyaluran dana ini diwujudkan dalam bentuk pinjaman atau lebih dikenal dengan istilah pembiayaan. Keuntungan dari pemanfatan dana dari nasabah yang disalurkan ke dalam berbagai usaha akan dibagikan kepada nasabah. Jumlah keuntungan yang dibagikan bersifat fluktuatif yaitu berdasarkan perkembangan keuangan perusahaan yang artinya semakin besar keuntungan yang dicapai, maka semakin besar bagi hasil yang akan diperoleh, baik bagi nasabah maupun bagi bank syariah.
Menurut Muhammad (2014) terkait dengan fungsi dan peran lembaga perbankan, maka secara khusus bank syariah secara nyata dapat terwujud dalam aspek-aspek, yaitu menjadi perekat nasionalisme baru, memberdayakan ekonomi umat dan beroperasi secara transparan, memberikan return yang lebih baik. mendorong penurunan spekulasi di pasar keuangan dan mendorong pemerataan pendapatan.

Begitu pentingnya fungsi dan peranan perbankan syariah di Indonesia, maka pihak Bank Syariah perlu meningkatkan kinerjanya agar tercipta perbankan dengan prinsip syariah yang sehat dan efisien. Profitabilitas merupakan indikator untuk mengukur kinerja suatu bank. Profitabilitas menggambarkan kemampuan perusahaan dalam mendapatkan laba melalui semua kemampuan dan sumber yang ada seperti kegiatan penjulan, kas, modal, jumlah karyawan, jumlah cabang, dan sebagainya (Harahap, 2013). Bank Indonesia telah menetapkan salah satu ukuran profitabilitas suatu bank adalah Return on Asset (ROA). ROA digunakan untuk mengukur efisiensi dan efektifitas perusahaan didalam menghasilkan keuntungan dengan memanfaatkan aktiva yang dimilikinya. ROA penting bagi bank karena ROA digunakan untuk mengukur 
efektivitas perusahaan di dalam menghasilkan keuntungan dengan memanfaatkan aktiva yang dimilikinya. Perusahaan dengan profitabilitas yang baik menunjukkan perusahaan mempunyai prospek yang baik, perusahaan akan mampu mempertahankan kelangsungan perusahaan dalam jangka panjang (Haryanto, 2016).

Bank ketika menyalurkan kredit akan dihadapkan pada risiko. Non Performing Financing (NPF) merupakan merupakan indikator dari risiko kredit (pembiayaan) bank. Bank dengan NPF yang tinggi cenderung kurang efisien. Sebaliknya bank dengan NPF yang rendah cenderung lebih efisien. Bank dengan NPF yang semakin rendah akan memiliki kemampuan menyalurkan dananya kepada nasabah lainnya sehingga tingkat profitabilitasnya akan semakin tinggi (Priantana dan Zulfia, 2011).

Hasil penelitian Nugroho (2011) menyatakan bahwa NPF berpengaruh Peranan modal sangat penting dalam usaha perbankan karena dapat mendukung kegiatan operasional bank agar dapat berjalan dengan lancar (Sari, 2013). Bank dengan Capital Adequacy Ratio (CAR) yang cukup besar akan mampu mendukung pengembangan operasi dan kelangsungan hidup bank serta menanggung risiko-risiko yang ditimbulkan termasuk di dalamnya risiko kredit sehingga akan mampu meningkatkan profitabilitas bank. Hasil penelitian pengaruh CAR terhadap profitabilitas menunjukkan hasil yang belum konsisten. Hasil penelitian Suardhika dan Anggreni (2014), menunjukkan CAR berpengaruh positif pada profitabilitas bank. Berbanding terbalik dengan hasil penelitian yang dilakukan oleh Havidz dan Setiawan (2015) yang menunjukkan pengaruh negatif CAR terhadap ROA.

Negatif signifikan terhadap ROA pada bank syariah berbeda dari hasil penelitian Kharisma dan Pratomo (2012) yang menyatakan bahwa NPF berpengaruh positif terhadap ROA. FDR (Financing to Deposit Ratio) adalah rasio seluruh jumlah pembiayaan yang diberikan bank dengan dana yang diterima oleh bank. Jika rasio tersebut semakin tinggi maka memberikan indikasi semakin rendahnya kemampuan likuiditas bank yang bersangkutan. Berkurangnya tingkat likuiditas dapat memberikan dampak terhadap naiknya profitabilitas. Hasil penelitian Nugraheni dan Alam (2014) menyatakan bahwa FDR berpengaruh positif terhadap ROA. Bertentangan dengan penelitian yang dilakukan oleh Armereo (2015) yang menyatakan bahwa FDR berpengaruh negatif terhadap ROA. 
Tabel 1

Perkembangan Rata-RataCAR, NPF, FDR, dan ROA

Bank Syariah di Indonesia Periode 2012-2016

\begin{tabular}{|c|r|r|r|r|r|}
\hline Variabel (\%) & \multicolumn{1}{|c|}{$\mathbf{2 0 1 2}$} & \multicolumn{1}{c|}{$\mathbf{1 0 1 3}$} & $\mathbf{2 0 1 4}$ & \multicolumn{1}{c|}{$\mathbf{1 0 1 5}$} & \multicolumn{1}{c|}{$\mathbf{2 0 1 6}$} \\
\hline CAR & 14,13 & 14,42 & 16,10 & 15,02 & 16,63 \\
\hline NPF & 2,22 & 2,62 & 4,33 & 4,84 & 4,42 \\
\hline FDR & 100,00 & 100,32 & 91,50 & 88,03 & 85,99 \\
\hline ROA & 2,14 & 2,00 & 0,80 & 1,08 & 0,63 \\
\hline
\end{tabular}

Sumber: Otoritas Jasa Keuangan

Berdasarkan Tabel 1, rata-rata CAR bank syariah pada tahun 2013 dan 2014 mengalami kenaikan berturut-turut sebesar $0,29 \%$ dan $1,68 \%$ akan tetapi ROA mengalami penurunan berturut-turut sebesar $0,14 \%$ dan $1,20 \%$. Hal tersebut tidak sesuai dengan teori yang menyatakan jika CAR mengalami kenaikan maka ROA juga akan mengalami kenaikan. Rata-rata NPF bank syariah tahun 2015 mengalami kenaikan sebesar $0,51 \%$, tetapi ROA juga naik sebesar 0,28\%. Hal tersebut tidak sesuai dengan teori yang menyatakan jika NPF mengalami kenaikan maka ROA akan mengalami penurunan. Rata-rata FDR bank syariah pada tahun 2013 naik sebesar 0,32\% akan tetapi ROA turun $0,14 \%$, kemudian pada tahun 2016 rata-rata FDR mengalami penurunan sebesar 2,04\% tetapi ROA mengalami kenaikan sebesar $0,14 \%$.Hal ini tidak sesuai dengan teori yang menyatakan jika FDR mengalami kenaikan maka ROA juga akan mengalami kenaikan dan jika FDR mengalami penurunan maka ROA juga akan mengalami penurunan. Berdasarkan fenomena gap tersebut, dapat ditarik kesimpulan bahwa tidak setiap kejadian empiris sesuai dengan teori yang ada. Hal ini diperkuat oleh adanya research gap dalam penelitian-penelitian terdahulu. Dengan adanya inkonsistensi hasil penelitian dan fenomena yang terjadi pada bank syariah, maka perlu diteliti lebih lanjut bagaimana pengaruh karakteristik bank terhadap profitabilitas perbankan syariah yang diproksikan dengan CAR, NPF dan FDR terhadap ROA.

\section{METODE PENELITIAN}

\section{Jenis Penelitian dan Populasi}

Penelitian ini termasuk dalam jenis deskriptif kuantitatif, yaitu penelitian yang menggambarkan dan menjelaskan variabel-variabel independen yang terdiri CAR, NPF dan FDR untuk dianalisis pengaruhnya terhadap variabel dependen, yaitu profitabilitas bank syariah di 
Indonesia. Populasi penelitian adalah keseluruhan dari obyek penelitian yang akan diteliti. Populasi penelitian ini adalah laporan keuangan perusahaan perbankan syariah di Indonesia yang terdiri dari Bank Umum Syariah dan Bank Unit Syariah.

Dalam penelitian ini mencoba untuk meneliti apakah rasio-rasio keuangan bisa dipakai dalam memprediksiperubahan laba pada perbankan syariah di Indonesia, periode penelitian dari Bulan Januari 2009 sampai bulan Desember 2016. Variabel dependen dalam penelitian ini adalah ROA, sedangkan variabel independennya adalah CAR, NPF dan FDR. Analisis deskriptif menggunakan data laporan keuangan bank syariah yang dapat diakses melalui website Bank Indonesia ataupun Otoritas Jasa Keuangan. Secara keseluruhan dari hasil uji asumsi klasik yang digunakan, dapat disimpulkan bahwa model regresi dalam penelitian ini memenuhi semua persyaratan uji asumsi klasik.

\section{Definisi Operasional Variabel}

Definisi operasional variable dalam penelitian ini dapat dilihat pada tabel berikut ini:

Tabel 2

Operasional Variabel

\begin{tabular}{|l|l|l|l|}
\hline No & \multicolumn{1}{|c|}{ Variabel } & \multicolumn{1}{|c|}{ Indikator } & Skala \\
\hline 1 & CAR $\left(\mathrm{X}_{1}\right)$ & $\begin{array}{l}\text { Diukur dengan rasio antara } \\
\text { total modal dengan ATMR }\end{array}$ & Rasio \\
\hline 2 & $\mathrm{NPF}\left(\mathrm{X}_{2}\right)$ & $\begin{array}{l}\text { Diukur dengan rasio antara } \\
\text { total pembiayaan } \\
\text { bermasalah dengan total } \\
\text { pembiayaan yang } \\
\text { disalurkan. }\end{array}$ & Rasio \\
\hline 3 & $\mathrm{FDR}\left(\mathrm{X}_{3}\right)$ & $\begin{array}{l}\text { Diukur dengan rasio antara } \\
\text { total pembiayaan dengan } \\
\text { total dana pihak ketiga. }\end{array}$ & Rasio \\
\hline 4 & $\begin{array}{l}\text { Profitabilitas } \\
(\mathrm{Y})\end{array}$ & $\begin{array}{l}\text { Diukur dengan rasio antara } \\
\text { laba sesudah pajak dengan } \\
\text { total aset. }\end{array}$ & Rasio \\
\hline
\end{tabular}

\section{Sumber Data}

Data yang digunakan dalam penelitian ini adalah data sekunder dalam bentuk deret waktu (time series) per bulan mulai tahun 2009-2016. Data yang digunakan adalah data CAR, NPF dan
FDR Perbankan Syariah dari website resmi melalui Bank Indonesia, yaitu www.bi.go.id, Otoritas Jasa Keuangan, yaitu www.ojk.go.id, dan sumber lain yang menunjang penelitian ini. 


\section{Hipotesis}

$\mathrm{H}_{1}$ : CAR berpengaruh positif terhadap

Profitabilitas bank syariah

$\mathrm{H}_{2}$ : NPF berpengaruh negatif terhadap

Profitabilitas bank syariah

$\mathrm{H}_{3}$ : FDR berpengaruh positif terhadap Profitabilitas bank syariah

\section{PEMBAHASAN}

\section{Profitabilitas}

Profitabilitas sangat penting bagi perbankan, karena digunakan sebagai indikator untuk mengukur efesiensi perusahaan dalam menghasilkan keuntungan dengan memanfaatkan aktiva yang dimilikinya. Indicator financial ratio yang digunakan adalah Return on Asset (ROA) sebagai variabel dependen. Dalam penelitian ini mengunakan ROA sebagai variabel dependennya karena Bank Indonesia sebagai pengawas dan pembina perbankan lebih mengutamakan nilai profitabilitas suatu bank yang diukur dengan aset. Profitabilitas adalah ukuran spesifik dari kinerja sebuah bank, dimana ROA merupakan tujuan dari manajemen perusahaan dengan memaksimalkan nilai dari para pemegang saham, optimalisasi dari berbagai tingkat return, dan minimalisasi resiko yang ada.

Untuk mengukur tingkat keuntungan suatu bank digunakan rasio profitabilitas.
Rasio profitabilitas merupakan rasio untuk menilai kemampuan bank dalam mencari keuntungan. Selain itu, rasio ini juga memberikan ukuran tingkat efektivitas manajemen suatu bank yang ditunjukkan oleh laba yang dihasilkan dari penjualan dan pendapatan investasi (Kasmir, 2015). Penggunaan seluruh atau sebagian rasio profitabilitas tergantung dari kebijakan manajemen. Dalam penelitian ini rasio profitabilitas yang digunakan adalah Return on Asset (ROA). Menurut Kasmir ROA atau hasil pengembalian investasi merupakan rasio yang menunjukkan hasil (return) atas jumlah aktiva yang digunakan dalam bank (Kasmir, 2011).

\section{Capital Adequacy Ratio (CAR)}

Modal merupakan salah satu faktor penting dalam lembaga keuangan syariah tetapi bukanlah yang terpenting. Modal digunakan untuk mencari keuntungan, namun tidak boleh berlebihan yang dapat menyebabkan kelalaian terhadap perintahNya. Perbankan Syariah harus melakukan seluruh aktifitasnya dengan motivasi akidah yang akan menjadikan para praktisinya selalu merasa bahwa aktifitas yang mereka lakukan tidak sekedar aktifitas yang bertujuan mencari keuntungan, tetapi juga menjadi salah satu cara berjihad dalam menyelamatkan 
umat/masyarakat dari praktek-praktek yang tidak sesuai dengan hukum Islam. Para praktisi bank syariah harus merasa bahwa aktifitasnya tersebut adalah ibadah yang akan mendapatkan pahala dari Allah SWT seiring dengan balasan materi duniawi yang akan didapatkan. Perencanaan usaha bank syariah harus dilandasi dengan prinsip usaha yang berkelanjutan dan mendasarkan pada keseimbangan duniawi dengan terciptanya kesejahteraan menuju tercapainya kemenangan yang abadi. Perbankan pada umumnya dan termasuk bank syariah adalah lembaga yang didirikan dengan orientasi laba. Untuk mendirikan lembaga demikian ini perlu didukung dengan aspek permodalan yang kuat. Modal merupakan salah satu faktor penting dalam rangka pengembangan usaha dan jaminan memperkecil risiko kerugian. Besarnya modal suatu bank akan berpengaruh pada mampu atau tidaknya suatu bank secara efisien menjalankan kegiatannya, dan dapat mempengaruhi tingkat kepercayaan masyarakat terhadap kinerja bank. Modal merupakan bagian dari dana yang dapat digunakan bank dalam aktivitas kesehariannya. Hal penting yang berkaitan dengan masalah dana adalah bagaimana melakukan aktivitas manajemen dana. Manajemen dana adalah proses pengelolaan penghimpunan dan pengalokasian dana masyarakat serta dana modal untuk mendapatkan tujuan bank syariah secara efektif dan efisien (Muhammad, 2014).

CAR adalah kecukupan modal yang menunjukkan kemampuan bank dalam mempertahankan modal yang mencukupi dan kemampuan manajeman bank dalam mengidentifikasi, mengukur, mengawasi, dan mengontrol risiko-risiko yang timbul yang dapat berpengaruh terhadap besarnya modal. Perhitungan CAR didasarkan pada prinsip bahwa setiap penanaman yang mengandung risiko harus disediakan jumlah modal sebesar persentase tertentu terhadap jumlah penanamannya. Sejalan dengan standar yang ditetapkan Bank for International Settlements (BIS), seluruh bank yang ada di indonesia diwajibkan untuk menyediakan modal minimum sebesar 8\% dari ATMR.

CAR merupakan rasio permodalan yang menunjukan kemampuan bank dalam menyediakan dana untuk keperluan pengembangan usaha serta menampung kemungkinan risiko kerugian yang diakibatkan dalam opersional bank. Semakin besar rasio tersebut akan semakin baik posisi modal. Menurut peraturan Bank Indonesia Nomor10/15/PBI/2008 pasal2 ayat1 tercantum bank wajib menyediakan modal minimum sebesar $8 \%$ dari aset tertimbang menurut risiko 
(ATMR). Perhitungan ATMR berpedoman pada ketentuan yang berlaku mengenai Kewajiban Penyediaan Modal Minimum (KPMM) bank umum berdasarkan prinsip syariah. Rasio dihitung per posisi penilaian termasuk memperhatikan tren KPMM. Hasil penelitian pengaruh CAR terhadap profitabilitas menunjukkan hasil yang belum konsisten. Hasil penelitian Suardhika and Anggreni (2014), menunjukkan Capital Adecuacy Ratio (CAR) berpengaruh positif pada profitabilitas bank. Berbanding terbalik dengan hasil penelitian yang dilakukan oleh Havidz and Setiawan (2015) yang menunjukkan pengaruh negatif CAR terhadap ROA.

\section{Non Performing Financing (NPF)}

Pada bank syariah istilah Non Performing Loan diganti menjadi Non Performing Financing (NPF) karena dalam bank syariah menggunakan prinsip pembiayaan. NPF merupakan tingkat risiko yang dihadapi bank. NPF adalah jumlah pembiayaan yang bermasalah dan ada kemungkinan tidak dapat ditagih. Sesuai dengan aturan yang telah ditetapkan oleh Bank Indonesia, besarnya NPF yang baik adalah dibawah 5\%. NPF diukur dari rasio perbandingan antara kredit bermasalah terhadap total kredit yang diberikan. Semakin besar NPF akan memperkecil keuntungan/profitabilitas bank karena dana yang tidak dapat ditagih mengakibatkan bank tidak dapat melakukan pembiayaan pada aktiva produktif lainnya. Hal ini mengakibatkan pendapatan bank menjadi berkurang sehingga profitabiltas perbankan akan terganggu.

\section{Financing to Deposit Ratio (FDR)}

FDR (Financing to Deposit Ratio) merupakan ukuran seberapa jauh kemampuan bank dalam membayar kembali penarikan dana yang dilakukan deposan dengan mengandalkan kredit yang diberikan sebagai sumber likuiditasnya. Jika bank dapat menyalurkan seluruh dana yang dihimpun memang akan menguntungkan, namun hal ini terkait risiko apabila sewaktu-waktu pemilik dana menarik dananya atau pemakai dana tidak dapat mengembalikan dana yang dipinjamnya. Secara lebih rinci FDR dapat dijelaskan sebagai rasio antara seluruh jumlah kredit yang diberikan bank dengan dana yang diterima bank. Rasio ini menunjukkan salah satu penilaian likuiditas bank. Berdasarkan ketentuan Bank Indonesia, besarnya standar nilai LDR menurut Bank Indonesia adalah antara 80\%-110\%. 
FDR adalah rasio seluruh jumlah pembiayaan yang diberikan bank dengan dana yang diterima oleh bank. Jika rasio tersebut semakin tinggi maka memberikan indikasi semakin rendahnya kemampuan likuiditas bank yang bersangkutan. Berkurangnya tingkat likuiditas dapat memberikan dampak terhadap naiknya profitabilitas. Jadi FDR memberikan pengaruh positif terhadap tingkat profitabilitas. Karena dengan tingginya
FDR maka penyaluran dana untuk pembiayaan semakin besar, sehingga dari macam-macam pembiayaan tersebut diharapkan dapat meningkatkan profitabilitas Bank Syariah.

\section{Analisis Data}

\section{Statistik Deskriptif Variabel}

Statistik deskriptif digunakan untuk menggambarkan suatu data secara statistik.

Tabel 3

\section{Statistik Deskriptif Variabel}

\begin{tabular}{|c|c|c|c|c|c|}
\hline & $\mathrm{N}$ & Minimum & Maximum & Mean & $\begin{array}{c}\text { Std. } \\
\text { Deviation }\end{array}$ \\
\hline CAR & 97 & 10,77 & 20,23 & 14,8290 & 1,68765 \\
NPF & 97 & 2,22 & 6,17 & 4,0879 & 1,06329 \\
FDR & 97 & 85,99 & 104,83 & 95,2967 & 5,50966 \\
ROA & 97 &, 08 & 2,52 & 1,4576 &, 65779 \\
Valid N & 97 & & & & \\
(listwise) & & & & & \\
\hline
\end{tabular}

Berdasarkan Tabel 3 dapat diketahui bahwa jumlah total data yaitu 96 buah yang berasal dari laporan keuangan bank syariah periode tahun 2009 sampai 2016. Rata-rata CAR selama periode pengamatan sebesar 14,8 dengan standar deviasi 1,69.
Hasil tersebut menunjukkan bahwa nilai standar deviasi lebih kecil daripada ratarata CAR yang mengindikasikan hasil yang baik. Hasil yang sama baiknya juga terjadi pada 3 (tiga) varibel yang lainnya yaitu NPF, FDR dan ROA. 


\section{Uji Asumsi Klasik}

\section{Tabel 4}

Hasil Uji Normalitas

One-Sample Kolmogorov-Smirnov Test

\begin{tabular}{|ll|r|}
\hline & & $\begin{array}{c}\text { Unstandardized } \\
\text { Residual }\end{array}$ \\
\hline $\mathrm{N}$ & Mean & 97 \\
Normal Parametersa & Std. Deviation & .0000000 \\
& Absolute & .44785687 \\
Most Extreme Differences & Positive & .075 \\
& Negative & .042 \\
& & -.075 \\
Kolmogorov-Smirnov Z & & .741 \\
Asymp. Sig. (2-tailed) & & .642 \\
\hline
\end{tabular}

a. Test distribution is Normal.

Uji Normalitas bertujuan untuk menguji apakah dalam model regresi variabel pengganggu memiliki distribusi normal atau tidak (Ghozali, 2013). Berdasarkan Tabel 4 pada bagian Asymp.
Sig. (2-tailed) tertera angaka 0,642 yang berarti apabila nilai probabilitas signifikansi lebih dari $\alpha \geq 0,05$, maka data pada penelitian ini terdistribusi secara normal.

Tabel 5

Hasil Uji Multikolinieritas

Coefficients $^{a}$

\begin{tabular}{|c|c|c|c|c|c|c|c|}
\hline \multirow[b]{2}{*}{ Model } & \multicolumn{2}{|c|}{$\begin{array}{l}\text { Unstandardized } \\
\text { Coefficients }\end{array}$} & \multirow{2}{*}{$\begin{array}{c}\begin{array}{c}\text { Standardized } \\
\text { Coefficients }\end{array} \\
\text { Beta }\end{array}$} & & \multirow[b]{2}{*}{ Sig. } & \multicolumn{2}{|c|}{$\begin{array}{l}\text { Collinearity } \\
\text { Statistics }\end{array}$} \\
\hline & B & $\begin{array}{l}\text { Std. } \\
\text { Error }\end{array}$ & & & & Tolerance & VIF \\
\hline 1 (Constant) & .278 & 1.347 & & .206 & .837 & & \\
\hline CAR & -.095 & .030 & -.244 & 3.126 & .002 & .821 & 1.218 \\
\hline NPF & -.307 & .055 & -.496 & 5.604 & .000 & .637 & 1.571 \\
\hline FDR & .040 & .010 & .338 & 3.944 & .000 & .680 & 1.471 \\
\hline
\end{tabular}

a. Dependent

Variable: ROA

Uji multikolinearitas bertujuan untuk menguji apakah model regresi ditemukan korelasi antar variabel bebas (independen). Model regresi yang baik seharusnya tidak terjadi korelasi diantara vaiabel independen (Ghozali, 
2013). Untuk mendeteksi multikolinieritas pada model regresi adalah dengan cara melihat nilai Tolerance dan nilai Variance Inflation Factor (VIF). Jika nilai Tolerance lebih dari 0,10 berarti tidak ada kolerasi antar variabel independen. Jika nilai Variance Inflation Factor (VIF) lebih besar dari
10, maka terjadi multikolinieritas (Ghozali, 2013). Pada Tabel 5 nilai Tolerance CAR, NPF dan FDR lebih dari 0,10 dan nilai Variance Inflation Factor (VIF) kurang dari 10 yang berarti data pada penelitian ini tidak terjadi multikolinieritas.

Tabel 6

Hasil Uji Heteroskedastisitas

Correlations

\begin{tabular}{|c|c|c|c|c|c|c|}
\hline & & & CAR & NPF & FDR & $\begin{array}{l}\text { Unstandardized } \\
\text { Residual }\end{array}$ \\
\hline \multirow{12}{*}{$\begin{array}{l}\text { Spearman's } \\
\text { rho }\end{array}$} & \multirow[t]{3}{*}{ CAR } & Correlation Coefficient & 1.000 & $-.276^{\star *}$ & $-.235^{*}$ & -.097 \\
\hline & & Sig. (2-tailed) & & .006 & .020 & .347 \\
\hline & & $\mathrm{N}$ & 97 & 97 & 97 & 96 \\
\hline & \multirow[t]{3}{*}{ NPF } & Correlation Coefficient & $-.276^{* *}$ & 1.000 & $-.481^{* *}$ & -.059 \\
\hline & & Sig. (2-tailed) & .006 & & .000 & .571 \\
\hline & & $\mathrm{N}$ & 97 & 97 & 97 & 96 \\
\hline & \multirow[t]{3}{*}{ FDR } & Correlation Coefficient & $-.235^{*}$ & $-.481^{* *}$ & 1.000 & .094 \\
\hline & & Sig. (2-tailed) & .020 & .000 & & .363 \\
\hline & & $\mathrm{N}$ & 97 & 97 & 97 & 96 \\
\hline & \multirow{3}{*}{$\begin{array}{l}\text { Unstandardized } \\
\text { Residual }\end{array}$} & Correlation Coefficient & -.097 & -.059 & .094 & 1.000 \\
\hline & & Sig. (2-tailed) & 347 & .571 & .363 & \\
\hline & & $\mathrm{N}$ & 96 & 96 & 96 & 96 \\
\hline
\end{tabular}

${ }^{* \star}$. Correlation is significant at the 0.01 level (2-tailed).

*. Correlation is significant at the 0.05 level (2-tailed).

Uji heteroskedastisitas bertujuan menguji apakah dalam model regresi terjadi ketidaksamaan variance dari residual satu pengamatan ke pengamatan yang lain. Model regresi yang baik adalah tidak terjadi Heteroskedastisitas (Ghozali, 2013).

Berdasarkan Tabel 6, terlihat bahwa korelasi rank spearman antara CAR dengan Sig. (2-tailed) adalah
0,347, korelasi rank spearman antara NPF dengan Sig. (2-tailed) adalah 0,571, dan korelasi rank spearman antara FDR dengan Sig. (2-tailed) adalah 0,363, maka masalah heteroskedastisitas dapat dikatakan tidak terjadi karena semua nilai korelasi rank spearman lebih besar dari 0,05. 


\section{Uji Autokorelasi}

Uji autokorelasi dapat dilakukan dengan cara uji Durbin-Watson (DW test). Untuk mendeteksi ada atau tidaknya autokorelasi, maka dilakukan pengujian Durbin-Watson dengan ketentuan sebagai berikut:

Tabel 7

Kriteria Nilai Uji Durbin-Watson

\begin{tabular}{|c|c|l|}
\hline No & Nilai DW & \multicolumn{1}{c|}{ Kesimpulan } \\
\hline 1 & $1,65<\mathrm{DW}<2,35$ & Tidak ada korelasi \\
\hline 2 & $1,21<\mathrm{DW}<1,65$ & Tidak dapat disimpulkan \\
\hline 3 & $2,35<\mathrm{DW}<2,79$ & Tidak dapat disimpulkan \\
\hline 4 & DW $<1,21$ & Terjadi autokorelasi \\
\hline 5 & DW $>2,79$ & Terjadi autokorelasi \\
\hline
\end{tabular}

Sumber: Sulaiman (2004)

\section{Tabel 8}

\section{Hasil Uji Autokorelasi}

\begin{tabular}{l|r|r|r|l|r|}
\hline Model & $\mathrm{R}$ & $\mathrm{R}$ Square & $\begin{array}{c}\text { Adjusted R } \\
\text { Square }\end{array}$ & $\begin{array}{c}\text { Std. Error of the } \\
\text { Estimate }\end{array}$ & Durbin-Watson \\
\hline 1 & $.899 \mathrm{a}$ & .809 & .800 &, 29391 & 2.126 \\
\hline
\end{tabular}
a. Predictors: (Constant), CAR, FDR, NPF
b. Dependent Variable: ROA

Berdasarkan Tabel 8 diketahui nilai

DW 2,126, selanjutnya nilai ini dibandingkan dengan nilai yang terdapat pada Tabel 7, posisi nilai DW 2,126 berada diantara $1,65<\mathrm{DW}<2,35$ yang artinya data pada penelitian ini tidak terdapat korelasi.

\section{Persamaan Regresi Linier Berganda}

Analisis regresi berganda dalam penelitian ini digunakan untuk mengetahui pengaruh CAR, NPF dan FDR terhadap ROA pada bank syariah di Indonesia periode tahun 2009 -2016. Model hubungan ROA dengan CAR,
NPF dan FDR dapat disusun dalam persamaan linier sebagai berikut:

$$
\mathrm{Y}=\mathrm{a}+\mathrm{b}_{1} \mathrm{X}_{1}+\mathrm{b}_{2} \mathrm{X}_{2}+\mathrm{b}_{3} \mathrm{X}_{3}+\mathrm{e}
$$

Di mana:

$$
\begin{array}{ll}
\mathrm{Y} & =\mathrm{ROA} \\
\mathrm{a} & =\text { konstanta } \\
\mathrm{b}_{1}, \mathrm{~b}_{2}, \mathrm{~b} 3 & =\text { koefisien regresi } \\
\mathrm{X}_{1} & =\text { CAR } \\
\mathrm{X}_{2} & =\mathrm{NPF} \\
\mathrm{X}_{3} & =\text { FDR } \\
\mathrm{e} & =\text { kesalahan residual (eror) }
\end{array}
$$




\section{Uji Hipotesis}

\section{Uji Koefisien Determinasi $\left(\mathbf{R}^{\mathbf{2}}\right)$}

Mengukur seberapa jauh kemampuan model dalam menerangkan variasi variabel dependen (Ghozali, 2013).
Nilai adjusted $\mathrm{R}^{2}$ yang mendekati satu berarti kemampuan variabel-variabel independen memberikan hampir semua informasi yang dibutuhkan untuk memprediksi variasi variabel dependen.

Tabel 9

Hasil Uji Determinasi

\begin{tabular}{|l|r|r|r|l|}
\hline Model & $\mathrm{R}$ & $\mathrm{R}$ Square & \multicolumn{1}{c|}{$\begin{array}{c}\text { Adjusted R } \\
\text { Square }\end{array}$} & $\begin{array}{c}\text { Std. Error of the } \\
\text { Estimate }\end{array}$ \\
\hline 1 & $.899 \mathrm{a}$ & .809 & .800 & .29391 \\
\hline
\end{tabular}

a. Predictors: (Constant), CAR, FDR, NPF

b. Dependent Variable: ROA

Berdasarkan Tabel 9 diperoleh angka R (koefisien korelasi) sebesar 0.899. Hal ini menunjukkan bahwa terjadi hubungan yang sangat kuat antara CAR, NPF dan FDR terhadap ROA. Hal ini didasarkan pada pedoman untuk memberikan interpretasi koefisien korelasi pada Tabel 10.

Tabel 10

Pedoman Interpretasi Koefisien

\begin{tabular}{|c|c|c|}
\hline No & Interval Koefisien & Tingkat Hubungan \\
\hline 1 & $0,00-0,199$ & Sangat rendah \\
\hline 2 & $0,20-0,399$ & Rendah \\
\hline 3 & $0,40-0,599$ & Sedang \\
\hline 4 & $0,60-0,799$ & kuat \\
\hline 5 & $0,80-1,000$ & sangat kuat \\
\hline
\end{tabular}

Sumber: Sugiyono (2013)

Hasil analisis koefisien determinasi $\left(\mathrm{R}^{2}\right)$ menunjukkan bahwa kontribusi pengaruh variabel independen (CAR, NPF dan FDR) terhadap variabel dependen (CAR) adalah sebesar 80,9\%. Sedangkan sisanya sebesar 19,1\% dipengaruhi oleh variabel lain yang tidak dimasukkan atau tidak dibahas dalam penelitian ini.

\section{Uji Statistik F (F-test)}

Menurut Ghozali (2013), Uji statistik F untuk menunjukkan apakah semua variabel independen yang dimaksud dalam penelitian mempunyai pengaruh secara simultan terhadap variabel dependen. Uji $F$ digunakan untuk mengetahui apakah variabel-variabel independen secara simultan berpengaruh signifikan terhadap variabel dependen. Derajat kepercayaan 
yang digunakan adalah 0,05. Apabila nilai $\mathrm{F}$ hasil perhitungan lebih besar daripada nilai $\mathrm{F}$ menurut tabel maka hipotesis alternatif, yang menyatakan bahwa semua variabel independen secara simultan berpengaruh signifikan terhadap variabel dependen.

Tabel 11

Hasil Uji F

ANOVA $^{b}$

\begin{tabular}{|ll|r|r|r|r|r|}
\hline Model & & Sum of Squares & df & Mean Square & F & Sig. \\
\hline 1 & Regression & 22.282 & 3 & 7.427 & 35.874 & $.000^{\mathrm{a}}$ \\
& Residual & 19.255 & 93 & .207 & & \\
& Total & 41.538 & 96 & & & \\
\end{tabular}

a. Predictors: (Constant), FDR, CAR, NPF

b. Dependent Variable: ROA

Berdasarkan Tabel 11, diketahui nilai signifikansi sebesar 0,000. Karena nilai signifikansi $0,000<0,005$, sesuai dengan dasar pengambilan keputusan pada Uji F, maka dapat disimpulkan bahwa varibel CAR, NPF dan FDR secara simultan berpengaruh terhadap Profitabilitas.

\section{Uji Statistik t (t-test)}

Uji $\mathrm{t}$ digunakan untuk mengetahui apakah variabel-variabel independen secara parsial berpengaruh nyata atau tidak terhadap variabel dependen. Derajat signifikansi yang digunakan adalah 0,05 .

Tabel 12

\section{Hasil Uji t}

\begin{tabular}{|c|c|c|c|c|c|c|}
\hline \multirow{2}{*}{\multicolumn{2}{|c|}{ Model }} & \multicolumn{2}{|c|}{$\begin{array}{l}\text { Unstandardized } \\
\text { Coefficients }\end{array}$} & \multirow{2}{*}{$\begin{array}{c}\begin{array}{c}\text { Standardized } \\
\text { Coefficients }\end{array} \\
\text { Beta }\end{array}$} & \multirow[b]{2}{*}{$t$} & \multirow[b]{2}{*}{ Sig. } \\
\hline & & $B$ & Std. Error & & & \\
\hline \multirow[t]{4}{*}{1} & (Constant) & .278 & 1.347 & & .206 & .837 \\
\hline & CAR & -.095 & .030 & -.244 & -3.126 & .002 \\
\hline & NPF & -.307 & .055 & -.496 & -5.604 & .000 \\
\hline & FDR & .040 & .010 & .338 & 3.944 & .000 \\
\hline
\end{tabular}

a. Dependent Variable: ROA

Berdasarkan Tabel 12 dapat diketahui arah dari koefisien beta regresi dan signifikansinya. tingkat signifikan variabel independen CAR sebesar 0,002, NPF sebesar 0,000 dan FDR sebesar 0,000, ketiga varibel independen memiliki 
tingkat signifikan di bawah 0,05. Berdasarkan cara pengambilan keputusan uji parsial dalam analisis regresi dapat disimpulkan bahwa variable CAR, NPF dan FDR secara parsial berpengaruh signifikan terhadap Profitablitas. Berikut penjelasan hasil perhitungan Uji t masingmasing variabel.

\section{H1: CAR berpengaruh positif terhadap}

\section{Profitabilitas (ROA)}

Nilai beta -0,244 menunjukkan bahwa CAR berpengaruh negatif terhadap Profitabilitas. Hasil yang negatif menunjukkan bahwa meningkatnya CAR tidak berdampak pada peningkatan Profitabilitas bank syariah. Karena nilai CAR adalah negatif sedangkan hipotesis yang diajukan adalah positif dapat disimpulkan $\mathrm{H}_{1}$ ditolak.

\section{$\mathrm{H}_{2}$ : NPF berpengaruh negatif terhadap Profitabilitas (ROA)}

Nilai beta $-0,496$ menunjukkan bahwa NPF berpengaruh negatif terhadap Profitabilitas. Hasil ini menunjukkan bahwa semakin besar NPF akan berdampak pada penurunan Profitabilitas bank syariah. Dapat disimpulkan $\mathrm{H}_{2}$ diterima.

\section{H3: FDR berpengaruh positif terhadap} Profitabilitas (ROA)
Nilai beta 0,338 menunjukkan bahwa FDR berpengaruh positif terhadap Profitabilitas. Hasil ini menunjukkan bahwa semakin besar FDR akan berdampak pada peningkatan Profitabilitas bank syariah. Dapat disimpulkan $\mathrm{H}_{3}$ diterima.

\section{Pembahasan Hasil Uji Statistik}

\section{Pengaruh CAR terhadap Profitabilitas}

Karena nilai CAR negatif sedangkan hipotesis yang diajukan adalah positif dapat disimpulkan $\mathrm{H}_{1}$ ditolak. CAR pada bank syariah di Indonesia pada tahun 2009-2016 yang tinggi tidak menyebabkan profitabilitas yang tinggi. Jika dilihat dari kondisi empiris dari obyek penelitian, maka akan tampak bahwa sebagian besar bank syariah mempunyai CAR di atas $8 \%$ dan memiliki rata-rata CAR sebesar 14,8\%. Hal ini dapat disebabkan karena bank syariah yang beroperasi pada tahun 2009-2016 tidak mengoptimalkan dana yang ada. Hal ni dapat terjadi karena peraturan Bank Indonesia yang mensyaratkan CAR minimal $8 \%$ mengakibatkan bank syariah berusaha selalu menjaga agar CAR yang dimiliki sesuai dengan peraturan yang berlaku.Hasil penelitian ini konsisten dengan penelitian yang dilakukan oleh Havidz and Setiawan (2015) yang menunjukkan bahwa CAR mempunyai 
pengaruh negatif terhadap profitabilitas (ROA).

\section{Pengaruh NPF terhadap Profitabilitas}

Hipotesis dalam penelitian ini menyebutkan bahwa NPF memiliki pengaruh negatif terhadap profitabilitas dan hasil uji $t$ menunjukkan bahwa koefisien variabel NPF negatif. Hal ini menunjukkan bahwa semakin besar NPF akan berdampak pada penurunan Profitabilitas. NPF yaitu rasio yang digunakan untuk mengetahui pembiayaan yang bermasalah terkait dengan kemungkinan bahwa pada saat jatuh tempo debitur dana gagal memenuhi kewajibannya terhadap bank.penelitian tingkat NPF perbankan syariah masih tergolong rendah, yaitu $4,08 \%$. Sehingga perlu adanya kehati-hatian pihak bank dalam menjalankan fungsinya. Risiko berupa kesulitan pengembalian pembiayaan oleh debitur dengan jumlah yang cukup besar dapat mempengaruhi kinerja bank. Terdapatnya pembiayaan bermasalah tersebut menyebabkan pembiayaan yang disalurkan banyak yang tidak memberikan hasil. Tingginya NPF juga mengakibatkan munculnya pencadangan yang lebih besar, sehingga pada akhirnya modal bank menjadi berkurang. Besarnya NPF menjadi salah satu penghambat tersalurnya pembiayaan perbankan. Peningkatan pembiayaan bermasalah ini menimbulkan pembentukan cadangan pembiayaan bermasalah ini menjadi semakin besar. Kerugian pembiayaan merupakan biaya yang berarti menurunkan laba. Tingginya nilai NPF dapat berdampak pada kesehatan bank. Semakin besar NPF maka semakin besar pula kerugian yang dialami bank, yang kemudian akan mengakibatkan berkurangnya keuntungan bank. Keuntungan yang berkurang akan mengakibatkan total asset bank tersebut juga ikut berkurang. Hasil penelitian ini konsisten dengan hasil penelitian Nugroho (2011) menyatakan bahwa NPF berpengaruh negatif signifikan terhadap ROA.

\section{Pengaruh FDR terhadap Profitabilitas}

Pada hipotesis dinyatakan bahwa FDR berpengaruh positif dan signifikan terhadap Profitabilitas. Dari hasil penelitian diperoleh nilai beta untuk variabel FDR bernilai positif. Hal ini menunjukkan bahwa semakin besarNPF akan berdampak pada peningkatan Profitabilitas. Hasil penelitian ini konsisten dengan hasil penelitian Nugraheni and Alam (2014) menyatakan bahwa FDR berpengaruh positif terhadap ROA. 


\section{SIMPULAN}

Berdasarkan hasil analisis dan pembahasan dapat disimpulkan bahwa nilai CAR, NPF dan FDR secara parsial berpengaruh signifikan terhadap profitabilitas. Nilai CAR dan NPF berpengaruh negatif terhadap profitabilitas, sedangkan FDRberpengaruh positif terhadap profitabilitas. Penelitiaan ini terbatas dengan variabel CAR, NPF dan FDR sebagai variabelprediktor profitabilitas bank. Untuk penelitian yang selanjutnya dapat dilakukan variabel yang lebih beragam untuk mengidentifikasi profitabilitas.

\section{DAFTAR PUSTAKA}

Anggreni, Made Ria, dan Suardhika, I Made Sadha. (2014). Pengaruh Dana Pihak Ketiga, Kecukupan Modal, Risiko Kredit dan Suku Bunga Kredit pada Profitabilitas. E-Jurnal Akuntansi Universitas Udayana.

Bank Indonesia. Laporan Keuangan Tahun 2009-2016. http://www.bi.go.id.

Ghozali, I. (2011). Aplikasi Analisis Multivariate dengan Program IBM SPSS 19.0. Semarang: Badan Penerbit Universitas Diponegoro.

Ghozali, Imam. (2013). Aplikasi Analisis dengan Program SPSS. Semarang: Undip.

Harahap, Sofyan Syafri. (2013). Analisis Kritis Atas Laporan Keuangan Edisi 11. Jakarta: Rajawali Pers.

Haryanto, Sugeng. (2016). Profitability Identification of National Banking
Through Credit, Capital Structure, Efficiency and Risk Level. JurnalDinamika Manajemen. Vol. 7 (1)

Havidz, Shinta Amalina Hazrati dan Setiawan, Chandra. (2015). The Determinants Of Roa (Return On Assets) Of Full-Fledged Islamic Banks In Indonesia. Jurnal MIX, Volume V, No. 1

Kasmir. (2015). Pengantar Manajemen Keuangan. Jakarta: Kencana.

Kasmir. (2011). Manajemen Perbankan. Jakarta: RajaGrafindo Persada.

Kharisma dan Pratomo. (2012). Pengaruh Dana Pihak Ketiga dan NonPerforming Financing Terhadap Profitabilitas PerbankanSyariah. Jurnal Ilmiah. Bandung: Universitas Telkom.

Muhammad. (2014). Manajemen keuangan syariah: analisis fiqh dan keuangan. Yogyakarta: UPP STIM YKPN.

Nugraheni, Peni dan Alam, Whinda Febrianti Iskandar. (2014). Pengaruh Risiko Likuiditas Terhadap Profitabilitas Pada Perbankan Syariah dan Konvensional Di Indonesia. Jurnal Akuntansi dan Investasi, Vol 15 NO. 1.

Nugroho, Elfianto. (2011). Analisis Pengaruh Likuiditas, Pertumbuhan Penjualan,Perputaran Modal Kerja, Ukuran Perusahaan dan LeverageTerhadapProfitabilitas Perusahaan (Studi Pada Perusahaan Manufaktur yangTerdaftar Pada BEI Pada Tahun 2005-2009). Semarang: Undip.

Otoritas Jasa Keuangan. Laporan Keuangan Tahun 2009-2016. http://www.ojk.go.id.

Peraturan Bank Indonesia No. 10/15/PBI/2008 Pasal 2 ayat 1. 
Priantana, Riha Dedi dan Zulfia. 2011. Pengaruh Rasio Kecukupan Modal, Non Performing Loan, dan Tingkat Likuiditas terhadap Profitabilitas Perbankan yang Terdaftar di Bursa Efek Indonesia. Jurnal Akuntansi danKeuangan. Vol. 1 (1).

Sari, Yulimel. (2013). Pengaruh Profitabilitas, Kecukupan Modal dan Likuiditas Terhadap Harga Saham (Perusahaan Perbankan yang
Terdaftar di BEI). Jurnal Akuntansi. Vol. 1(1).

Sugiyono. (2012). Metode Penelitian Bisnis (Pendekatan Kuantitatif, Kualitatif, dan R\&D). Bandung: Al+-----vabeta.

Sulaiman, Wahid. (2004). Analisis Regresi Menggunakan SPSS, Contoh Kasus dan Pemecahannya. Yogyakarta: Andi. 